\title{
Deskripsi Kemampuan Pemecahan Masalah Matematika Ditinjau dari Tingkat Kecerdasan Logis Matematis Siswa Kelas XI
}

\author{
Nurdin Arsyad ${ }^{1, a)}$, Nasrullah ${ }^{1, \text { b) }}$, dan Satriani Safaruddin ${ }^{1, c)}$ \\ ${ }^{1}$ Jurusan Matematika, Fakultas MIPA, Universitas Negeri Makassar \\ a)nurdin.arsyad@unm.ac.id \\ b)nasrullah.niswar@gmail.com \\ c) satrianisafaruddin96@gmail.com
}

\begin{abstract}
Abstrak. Penelitian ini merupakan penelitian kualitatif dengan pendekatan deskriptif bertujuan mendeskripsikan kemampuan pemecahan masalah matematika berdasarkan tingkat kecerdasan logis matematis pada materi barisan dan deret. Subjek dalam penelitian ini sebanyak 32 siswa kelas XI. Teknik pengumpulan data yang dilakukan dalam penelitian ini adalah metode tes dan wawancara. Hasil penelitian menunjukkan bahwa dari ketiga tingkatan kecerdasan logis matematis, subjek penelitian memiliki kesamaan, dimulai pada tahap memahami masalah subjek mengungkapkan maksud soal dengan bahasa dan kalimat sendiri. Kemudian dalam menyusun rencana pemecahan masalah subjek membuat model matematika. Pada tahap melaksanakan rencana, subjek menentukan nilai-nilai variabel yang dibutuhkan untuk menemukan solusi dari masalah, dan di akhir proses pemecahan masalah subjek memeriksa kembali langkah-langkah yang digunakan dan hasil yang diperoleh. Selain itu, dari ketiga tingkatan kecerdasan logis matematis subjek penelitian memiliki perbedaan, yaitu pada tahap memahami masalah dimana informasi yang diungkapkan subjek KLMT lebih lengkap daripada subjek KLMS dan KLMR. Sementara itu, pada tahap melaksanakan rencana dalam menggunakan prosedur pemecahan masalah subjek KLMT lebih jelas dan tepat. Sedangkan, subjek KLMS dapat menyelesaikan rencana penyelesaiannya yang jawaban akhirnya benar, meskipun prosedur yang digunakan kurang tepat. Kemudian, subjek KLMR menghadapi kendala dalam menyelesaikan masalah karena prosedur yang digunakan tidak jelas.
\end{abstract}

Kata Kunci: Kemampuan, Pemecahan masalah matematika, Langkah Polya, Kecerdasan logis matematis, Barisan dan deret.

\begin{abstract}
This research is a qualitative research with a descriptive approach that aimed to describe students' mathematical problem solving ability in terms the level of mathematical logical intelligence on sequence and series topic. The subjects in this research were 32 students of class XI MIA. The data collection techniques used in this research were the method of test and interview. The results of the research showed that of the three levels of mathematical logical intelligence, research subjects have similarities, starting at the step of understanding the problem subjects expressed the purpose of the problem with their own language and sentence. Then in devising a problem solving plan subjects make a mathematical model. At the step of carrying out the plan, the subjects determine the variable values needed to find a solution to the problem, and at the end of the problem solving process, subjects looking back the steps used and the results obtained. Meanwhile, from the three levels of mathematical logical intelligence, research subjects have differences, that are at the step of understanding the problem where the information revealed by the subject of KLMT is more complete than the subject of KLMS and KLMR. Meanwhile, at the step of carrying out the plan the subject of KLMT in using problem solving procedure more clear and precise. While, the subject of KLMS was able to complete the completion plan whose answer was finally correct, although the procedure used was incorrect. Then, the subject of KLMR faced an obstacle in solving problems because the procedure used was unclear.
\end{abstract}


Keywords: Ability, Mathematical problem solving, Polya steps, Mathematical logical intelligence, Sequence and series.

\section{PENDAHULUAN}

Masalah dalam matematika biasanya direpresentasikan ke dalam bentuk soal atau pertanyaan yang bersifat menantang dan tidak secara langsung dapat diselesaikan oleh siswa. Akan tetapi, tidak semua soal akan menjadi masalah pada siswa. Setiap siswa memiliki strategi sendiri dalam menyelesaikan masalah matematika yang dihadapi. Masalah matematika adalah suatu pertanyaan matematika yang memerlukan solusi/jawaban tetapi tidak dengan segera ditemukan ide atau aturan untuk memecahkannya (Mahalistia, 2017). Hal ini sejalan dengan Mahardhikawati (2017) yang menyatakan bahwa suatu soal disebut masalah bagi seorang siswa, jika: 1) pertanyaan yang dihadapkan dapat dimengerti oleh siswa, namun pertanyaan itu harus merupakan tantangan baginya untuk menjawabnya dan 2) pertanyaan tersebut tidak dapat dijawab dengan prosedur rutin yang telah diketahui siswa.

Menyelesaikan masalah merupakan proses untuk menerima tantangan untuk menjawab masalah (Hudojo, 1990). Kemampuan pemecahan masalah merupakan salah satu tujuan pembelajaran matematika yang diharapkan dapat dimiliki oleh siswa. Akan tetapi, kemampuan pemecahan masalah yang dimiliki oleh siswa berbeda-beda. Irawan (2016) menyatakan bahwa faktor internal yang mempengaruhi kemampuan pemecahan masalah matematika adalah kecerdasan logis matematis.

Pada pembelajaran di kelas, siswa dengan kecerdasan logis matematis yang baik cenderung tertarik dengan kegiatan menganalisis dan berpikir secara logis. Setiap siswa memiliki jenis dan tingkat kecerdasan yang berbeda-beda dalam kelas yang tidak dapat disamakan antara siswa yang satu dengan yang lainnya. Penelitian Zulfairanatama (2013) menunjukkan bahwa jika kecerdasan logis matematis meningkat, maka kemampuan matematika juga akan meningkat, dan sebaliknya. Kemampuan matematika siswa sangat bervariasi, disebabkan oleh kombinasi kecerdasan-kecerdasan yang berbeda antara satu siswa dengan siswa lain.

Strategi pemecahan masalah yang dapat digunakan oleh siswa di lingkungan akademis dengan kecerdasan logis matematis adalah heuristika logis (Polya) (Armstrong, 2002). Jika seseorang memiliki kecerdasan logis matematis yang berkembang dengan baik maka seseorang tersebut mempunyai kapasitas mengelola logika dan angka, dengan aktivitas utama berpikir logis, berhitung, menyusun pola hubungan dan pemecahan masalah (Prasetyo, 2009). Kecerdasan logis matematis yang baik dapat membantu siswa dalam menyelesaikan masalah untuk menemukan solusi yang tepat.

Menyelesaikan masalah matematika dapat merujuk pada empat tahapan Polya (1973) yaitu: (1) memahami masalah (Understanding the problem), (2) memikirkan rencana (Devising a plan), (3) melaksanakan rencana (Carrying out the plan), dan (4) memeriksa kembali jawaban (Looking back). Setiap tahapan pemecahan masalah dapat mengarahkan siswa untuk menemukan solusi dari suatu permasalahan. Pemecahan masalah berdasarkan langkah Polya dalam penelitian ini digunakan untuk menggambarkan bagaimana kemampuan siswa dalam menyelesaikan masalah matematika.

Penelitian Mahardhikawati (2017) menunjukkan bahwa terdapat kaitan antara kecerdasan logis matematis dengan kemampuan pemecahan masalah siswa. Kecerdasan logis matematis meliputi empat kemampuan, yaitu kemampuan numerik, kemampuan konsep aljabar, kemampuan deret bilangan, dan kemampuan logika (penalaran). Kemampuan tersebut berkaitan dengan langkahlangkah yang ditempuh siswa dalam memecahkan masalah matematika.

Penelitian ini mengidentifikasi kemampuan siswa dalam menyelesaikan masalah matematika berdasarkan tahapan Polya. Siswa dikategorikan berdasarkan tingkat kecerdasan logis matematis. Penelitian ini bertujuan untuk mendeskripsikan kemampuan pemecahan masalah 
matematika ditinjau dari tingkat kecerdasan logis matematis siswa pada materi barisan dan deret kelas XI MIA.

\section{KAJIAN PUSTAKA}

\section{Kemampuan Pemecahan Masalah Matematika}

Pemecahan masalah adalah suatu serangkaian proses tertentu yang dilakukan siswa dalam menghadapi situasi yang direpresentasikan ke dalam pertanyaan dan pertanyaan disadari oleh siswa, serta menantang untuk diselesaikan meskipun tidak dapat segera ditentukan strategi untuk menjawab pertanyaan yang dihadapi (Mahardhikawati, 2017). Menurut Polya (1973) untuk mempermudah memahami dan menyelesaikan suatu masalah, terlebih dahulu masalah tersebut disusun menjadi masalah-masalah sederhana, lalu dianalisis (mencari semua kemungkinan langkah-langkah yang akan ditempuh), kemudian dilanjutkan dengan proses sintesis (memeriksa kebenaran setiap langkah yang dilakukan). Adapun langkah-langkah pemecahan masalah menurut Polya (1973), yaitu:

1. Memahami masalah

Pada tahap ini, siswa dituntut untuk memahami masalah dengan baik dan mengungkapkan informasi-informasi yang terdapat pada soal atau pertanyaan dengan tepat serta menentukan hal yang diketahui dan ditanyakan secara lengkap dan tepat.

2. Menyusun rencana pemecahan masalah

Pada tahap ini, siswa dituntut untuk mengaitkan informasi-informasi yang ada dengan strategi yang dapat digunakan untuk menyelesaikan masalah. Siswa pada tahap ini memiliki rencana pemecahan masalah yang relevan dan rencana tersebut dapat mengarah pada solusi untuk memecahkan masalah dengan mengaitkan informasi-informasi yang ada.

3. Melaksanakan rencana pemecahan masalah

Pada tahap ini, siswa dituntut untuk menggunakan prosedur untuk menyelesaikan masalah dengan strategi yang digunakan dengan tepat dan melaksanakan langkahlangkah rencana penyelesaian masalah dengan benar serta melakukan perhitungan yang tepat.

4. Memeriksa kembali jawaban penyelesaian masalah

Pada tahap ini, siswa dituntut untuk memeriksa kembali prosedur dan langkah-langkah pemecahan masalah yang digunakan secara teliti dan menyeluruh untuk menafsirkan kebenaran hasil yang diperoleh untuk menemukan solusi yang tepat.

Pemecahan masalah berdasarkan tahapan Polya dapat digunakan oleh siswa untuk menyelesaikan masalah hingga menemukan solusi yang tepat. Hal ini sejalan dengan penelitian Hadi (2014) yang menunjukkan bahwa metode pemecahan masalah menurut Polya dapat mengembangkan kemampuan pemecahan masalah siswa. Selain itu, menunjukkan bahwa terdapat perbedaan hasil belajar dari metode pemecahan masalah menurut Polya terhadap kemampuan pemecahan masalah matematis siswa.

\section{Kecerdasan Logis Matematis}

Kecerdasan logis matematis adalah kemampuan menggunakan angka dengan baik dan melakukan penalaran yang benar (Armstrong, 2002). Kecerdasan ini meliputi kepekaan pada pola dan hubungan logis, serta pernyataan dan dalil (jika-maka, sebab-akibat). Proses yang digunakan dalam kecerdasan logis matematis ini antara lain: kategorisasi, klasifikasi, pengambilan kesimpulan, generalisasi, perhitungan, dan pengujian hipotesis. 
Kemampuan dalam kecerdasan logis matematis meliputi: a) kemampuan numerik berkaitan dengan kecermatan dan kecepatan dalam penggunaan perhitungan, b) kemampuan pola bilangan berkaitan dengan kemampuan mengurutkan, mendeteksi serta menganalisis pola angka-angka tertentu dan c) kemampuan logika (penalaran) berkaitan dengan kemampuan dalam berpikir secara induktif dan deduktif, berpikir menurut aturan logika, memahami dan memecahkan masalah dengan menggunakan kemampuan berpikir. Seseorang dengan kecerdasan logis matematis akan melibatkan kemampuannya untuk menganalisis masalah secara logis, menemukan atau menciptakan rumus-rumus atau pola matematika dan menyelidiki masalah secara ilmiah dalam memecahkan masalah matematika.

Setiap individu memiliki tingkat kecerdasan yang berbeda-beda sehingga mereka juga memiliki caranya sendiri dalam menyelesaikan masalah yang dihadapi. Hasil penelitian Jayantika (2013) menyimpulkan bahwa bakat numerik dan kecerdasan logis matematis berkontribusi terhadap prestasi belajar matematika. Bakat numerik dan kecerdasan logis matematis merupakan faktor penting yang menentukan prestasi belajar matematika nantinya, sehingga untuk meningkatkan prestasi belajar matematika dapat diupayakan dengan mengembangkan bakat numerik dan meningkatkan kecerdasan logis matematis siswa. Selain itu, hasil penelitian Irawan (2016) menunjukkan bahwa kecerdasan logis matematis membuat siswa dapat mengaitkan informasiinformasi yang terdapat dalam masalah dengan metode-metode yang tepat untuk menyelesaikan masalah matematika dan dalam melakukan perhitungan matematis.

\section{METODE PENELITIAN}

Penelitian ini merupakan penelitian kualitatif dengan pendekatan deskriptif. Penelitian ini mendeskripsikan kemampuan pemecahan masalah matematika berdasarkan langkah Polya ditinjau dari tingkat kecerdasan logis matematis siswa. Subjek penelitian ini adalah siswa kelas XI MIA. Pengambilan subjek penelitian didasarkan pada hasil tes kecerdasan logis matematis dengan menganalisis skor kecerdasan logis matematis setiap siswa. Pengambilan subjek didasarkan pada tingkat kecerdasan logis matematis seperti pada Tabel 1, selanjutnya dipilih subjek penelitian yang terdiri dari 3 orang yaitu 1 orang dengan kecerdasan logis matematis tinggi, 1 orang dengan kecerdasan logis matematis sedang, dan 1 orang dengan kecerdasan logis matematis rendah. Siswa dikategorikan berdasarkan hasil tes yaitu:

$$
P=\frac{S}{N} \times 100 \quad \text { (Amri, 2017) }
$$

Keterangan: $\quad P=$ Nilai yang diperoleh hasil konversi

$S=$ Jumlah skor yang diperoleh

$N=$ Skor tertinggi yang mungkin dicapai

TABEL 1 Pengkategorian Kecerdasan Logis Matematis

\begin{tabular}{cc}
\hline Interval skor & Kategori \\
\hline $0 \leq x \leq 50$ & Rendah \\
$50<x \leq 75$ & Sedang \\
$75<x \leq 100$ & Tinggi \\
\hline
\end{tabular}

TABEL 2 Identitas Subjek Penelitian

\begin{tabular}{cc}
\hline Tingkat Kecerdasan Logis Matematis & Subjek \\
\hline Tinggi & KLMT \\
Sedang & KLMS \\
Rendah & KLMR \\
\hline
\end{tabular}


Teknik pengumpulan data yang digunakan antara lain: (1) metode tes meliputi tes kecerdasan logis matematis yang memuat soal-soal untuk mengukur kecerdasan logis matematis dan tes kemampuan pemecahan masalah matematika yang memuat soal pemecahan masalah tentang barisan dan deret, (2) metode wawancara untuk mengungkap secara terperinci dan mengonfirmasi kemampuan pemecahan masalah subjek penelitian. Instrumen dalam penelitian ini yaitu tes kecerdasan logis matematis, tes kemampuan pemecahan masalah matematika dan pedoman wawancara. Teknik analisis data dalam penelitian ini adalah analisis data kualitatif.

Adapun teknik analisis data kualitatif dilakukan dalam tiga tahap, yaitu 1) kondensasi data dalam penelitian ini merujuk pada proses memilih, menyederhanakan, mengabstrakkan, dan mentransformasikan data mentah di lapangan, 2) penyajian data dalam penelitian ini adalah pengklasifikasian dan identifikasi mengenai kemampuan siswa dalam memahami masalah, merencanakan penyelesaian masalah, melakukan rencana penyelesaian masalah dan melihat kembali hasil penyelesaian berdasarkan hasil tes dan transkrip wawancara dan kemudian dianalisis dengan memperhatikan indikator kemampuan pemecahan masalah, dan 3) penarikan kesimpulan berdasarkan hasil analisis data yang telah dikumpulkan melalui pengamatan, rekaman wawancara, catatan lapangan, serta data hasil tes kecerdasan logis matematis dan tes pemecahan masalah matematika yang telah direduksi.

\section{HASIL DAN PEMBAHASAN}

\section{Siswa dengan tingkat kecerdasan logis matematis tinggi (KLMT)}

Berikut ini disajikan hasil tes dan transkrip wawancara siswa untuk setiap tahapan pemecahan masalah berdasarkan langkah Polya.

\section{Tahap memahami masalah}

\begin{tabular}{l} 
Dik: -7 kotak berlabel $A, B, C, D, E, f, 6$. dgn banjan geametri \\
- kotak $C$ disi 16 butir kelereng. \\
\hline- kotak 6 dilsi 2.56 butir kelereng. \\
Dit: jumlahtotal kelereng dalam 7 kotak?
\end{tabular}

GAMBAR 1. Hasil Tes Siswa KLMT

Pada Gambar 1 siswa KLMT mengungkapkan informasi-informasi yang diberikan dengan lengkap dan tepat dari soal. Siswa KLMT menentukan hal yang diketahui dan yang ditanyakan dari soal dengan tepat. Dalam hal ini, subjek dapat memahami masalah yang diberikan dengan baik.

Tahap menyusun rencana penyelesaian masalah

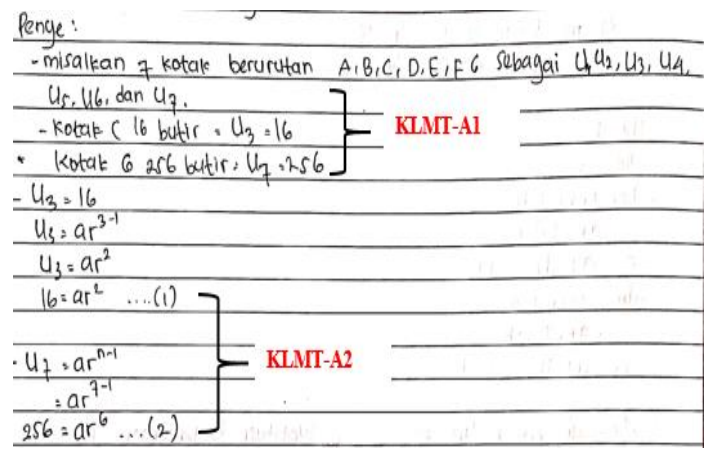

GAMBAR 2. Hasil Tes Siswa KLMT 
Pada Gambar 2 siswa KLMT menyusun rencana penyelesaian masalah dengan membuat pemisalan dari hal yang diketahui (KLMT-A1) dan siswa membuat model matematika yang sederhana dengan menggunakan rumus yang relevan dengan materi barisan geometri (KLMTA2). Siswa KLMT menemukan keterkaitan antara hal-hal yang diketahui untuk menentukan hal-hal yang dibutuhkan untuk menyelesaikan masalah. Dalam hal ini, siswa KLMT dalam menyusun rencana penyelesaian, siswa memiliki rencana pemecahan masalah dan rencana tersebut dapat membantunya dalam menyelesaikan masalah dengan tepat

Melaksanakan penyelesaian masalah

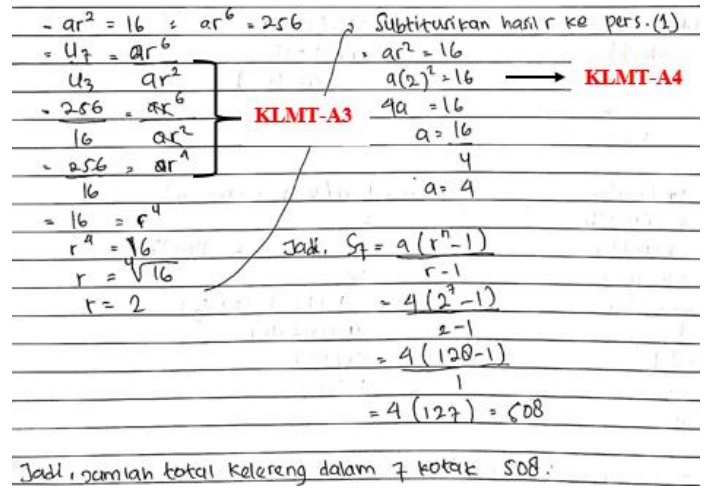

GAMBAR 3. Hasil Tes Siswa KLMT

Pada Gambar 3 siswa KLMT menyelesaikan masalah sesuai dengan strategi yang telah direncanakan pada langkah sebelumnya. Langkah yang dilakukan siswa KLMT adalah menggunakan metode perbandingan dengan menggunakan model matematika yang telah dibuat sebelumnya (KLMT-A3). Selanjutnya siswa KLMT menggunakan metode subtitusi untuk menemukan nilai variabel yang belum diketahui dalam menyelesaikan masalah (KLMT-A4). Selain itu, siswa KLMT melakukan perhitungan dengan benar. Dalam hal ini, siswa KLMT dapat melaksanakan langkah-langkah rencana pemecahan masalah yang telah dibuat dengan prosedur yang tepat.

Memeriksa kembali jawaban penyelesaian

\section{TRANSKRIP 1}

P11-026

: "Setelah mengerjakan permasalahan tersebut? Apakah adek sudah mengetahui jawabannya benar atau salah?"

KLMT-14-026 : "Iya, benar".

P12-027 : "Apakah setelah mengerjakan permasalahan tersebut, adek mengecek jawaban yang dibuat?"

KLMT-14-027 : "Iya".

P12-028 : "Bagaimana caranya?

KLMT-14-028 : Kulihat saja kak cara kerjanya sama cara hitungnya.

P12-029 : Dari awal sampai akhir?

KLMT-14-029 : Iya, harusnya.

Pada Transkrip 1 siswa KLMT menjelaskan bahwa memeriksa kembali setiap langkah pemecahan masalah yang digunakan secara menyeluruh beserta jawabannya. Siswa KLMT memeriksa kembali jawaban dengan cara memperhatikan dari awal hingga akhir langkah penyelesaian masalah yang digunakan (KLMT-14-029) dan memeriksa perhitungan yang dilakukan (KLMT-14-028). Selain itu, siswa KLMT yakin benar dengan jawaban yang diperolehnya (KLMT-14-026). 


\section{Siswa dengan tingkat kecerdasan logis matematis sedang (KLMS)}

Berikut ini disajikan hasil tes dan transkrip wawancara siswa untuk setiap tahapan pemecahan masalah berdasarkan langkah Polya.

\section{Memahami masalah}

Dik: Ukuran kain batik $=2.5 \mathrm{~m} \times 1.6 \mathrm{~m}$
$U_{4}=15$
$U_{10}=33$
Harga per helai $=750.000 .00 /$ per helai
Dit : Un di hatga?

GAMBAR 4. Hasil Tes Siswa KLMS

Pada Gambar 4 siswa KLMS mengungkapkan informasi-informasi yang diberikan dengan kurang lengkap dari soal. Siswa KLMS menentukan hal yang diketahui dari soal, namun kurang tepat dalam menentukan hal yang ditanyakan dari soal. Siswa KLMS membuat sebuah pemisalan pada hal yang diketahui dari soal. Dalam hal ini, siswa KLMS cukup dapat memahami masalah.

Menyusun rencana penyelesaian masalah

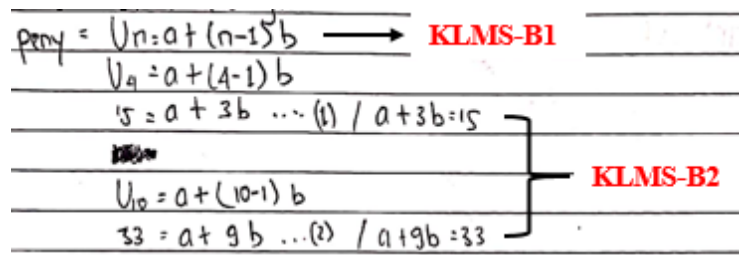

\section{GAMBAR 5 Hasil Tes Siswa KLMS}

Pada Gambar 5 siswa KLMS menyusun rencana penyelesaian masalah dengan menentukan rumus yang relevan dengan materi barisan aritmetika (KLMS-B1). Siswa KLMS membuat model matematika yang sederhana untuk menyelesaikan masalah (KLMS-B2). Dalam hal ini, siswa KLMS dalam menyusun rencana penyelesaian, siswa memiliki rencana pemecahan masalah dan rencana tersebut dapat membantunya dalam memecahkan masalah.

Melaksanakan penyelesaian masalah

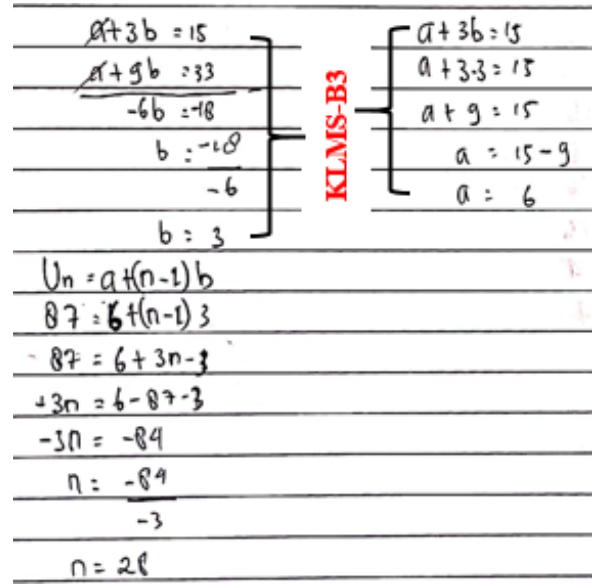

GAMBAR 6 Hasil Tes Siswa KLMS

Pada Gambar 6 siswa KLMS menyelesaikan masalah sesuai dengan strategi yang telah direncanakan pada langkah sebelumnya. Siswa KLMS menggunakan metode eliminasi dan metode subtitusi untuk menentukan nilai variabel yang belum diketahui dalam menyelesaikan 
masalah (KLMS-B3). Siswa KLMS menggunakan prosedur dengan tepat, akan tetapi siswa tidak menyelesaikan proses pemecahan masalah hingga memperoleh solusi yang tepat dari masalah yang diberikan. Hal ini dipertegas pada Transkrip 2.

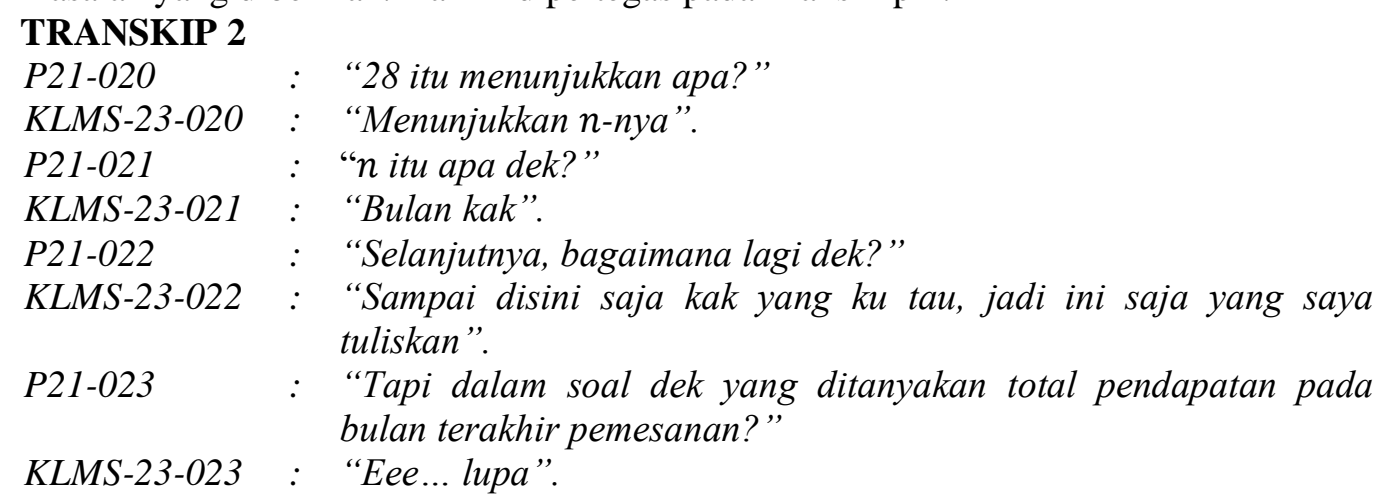

Pada Transkrip 2, siswa KLMS menjelaskan mengenai penyelesaian masalah yang tidak diselesaikan hingga memperoleh solusi yang tepat dari masalah karena tidak mengetahui langkah yang harus dilakukan selanjutnya untuk menyelesaikan soal (KLMS-23-022). Siswa KLMS juga menjelaskan bahwa tidak mengingat hal yang ditanyakan dari soal (KLMS-23-023). Dalam hal ini, siswa KLMS kurang dapat melaksanakan pemecahan masalah.

Memeriksa kembali jawaban penyelesaian

\section{TRANSKRIP 3}

P21-025 : "Setelah mengerjakan soal tadi, apakah adek sudah tau jawabannya benar atau salah?"

KLMS-24-025 : "Eee... Iya".

P22-026 : "Apakah adek mengecek kembali tiap langkah yang digunakan?"

KLMS-24-026 : "Mengecek".

P22-027 : "Bagaimana cara mengeceknya?"

KLMS-24-027 : "Eee... ku hitung saja kak".

P22-028 : "Tapi kenapa tidak diselesaikan dek?"

KLMS-24-028 : "Saya lupa".

Pada Transkrip 3, siswa KLMS menjelaskan bahwa memeriksa kembali penyelesaian setelah mengerjakan soal yaitu mengecek kembali jawaban dengan hanya memperhatikan perhitungan yang dilakukan (KLMS-24-026 dan KLMS-24-027). Siswa KLMS menyadari bahwa tidak menyelesaikan masalah hingga memperoleh solusi yang tepat karena tidak mengingat hal yang ditanyakan dari soal (KLMS-24-028). Selain itu, siswa KLMS yakin benar dengan jawaban yang diperolehnya (KLMS-24-025).

\section{Siswa dengan tingkat kecerdasan logis matematis rendah (KLMR)}

Berikut ini disajikan hasil tes dan transkrip wawancara siswa untuk setiap tahapan pemecahan masalah berdasarkan langkah Polya.

\section{Memahami masalah}

Dik: $C=16$ butir $]$ KLMR-Cl
$G: 256$ butir $]$
Dik: Jumlah Seluruh kelereng tang di isikan ke dalam 7 kotak tsb.

GAMBAR 7 Hasil Tes Siswa KLMR

Pada Gambar 7 siswa KLMR mengungkapkan informasi-informasi yang diberikan dengan kurang lengkap dan tepat dari soal. Siswa KLMR menentukan hal yang diketahui dengan 
kurang lengkap, namun siswa menentukan hal yang ditanyakan dengan tepat pada soal. Selain itu, siswa KLMR membuat pemisalan yang sederhana dari masalah yang diberikan (KLMRC1). Dalam hal ini, siswa KLMR cukup dapat memahami masalah.

\section{Menyusun rencana penyelesaian masalah}

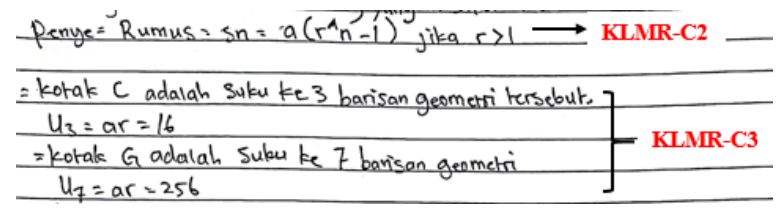

GAMBAR 8 Hasil Tes Siswa KLMR

Pada Gambar 8 siswa KLMR menyusun rencana penyelesaian masalah dengan menentukan rumus yang relevan dengan materi deret geometri (KLMR-C2), namun rumus tersebut kurang tepat dapat digunakan dalam menyelesaikan masalah. Subjek KLMR menentukan pemisalan dari hal yang diketahui dengan kurang tepat (KLMR-C3). Siswa KLMR membuat model matematika yang sederhana namun kurang tepat dapat digunakan untuk menyelesaikan masalah (KLMR-C3). Dalam hal ini, siswa KLMR siswa memiliki rencana pemecahan masalah, akan tetapi rencana pemecahan masalah tersebut kurang dapat membantunya dalam menyelesaikan masalah. Hal ini dipertegas pada Transkrip 4.

\section{TRANSKRIP 4}

P32-020

: "Bagaimana strategi yang digunakan untuk menyelesaikian soal ini?"

KLMR-32-020 : "Dengan menentukan rumus $S_{n}=a\left(r^{n}-1\right)$ jika $r>1$ ".

P32-021 : "Kenapa gunakan rumus ini?"

KLMR-32-021 : "Karena itu saja yang saya tau rumusnya kak".

Pada Transkrip 4, siswa KLMR menjelaskan menentukan rumus yang digunakan dalam menyelesaikan masalah karena hanya rumus tersebut yang diketahui (KLMR-32-020 dan KLMR-32-021). Akan tetapi, rumus yang digunakan siswa KLMR kurang tepat dapat membantunya dalam menyelesaikan masalah. Dalam hal ini, siswa KLMR kurang dapat menyusun rencana penyelesaian masalah.

\section{Melaksanakan penyelesaian masalah}

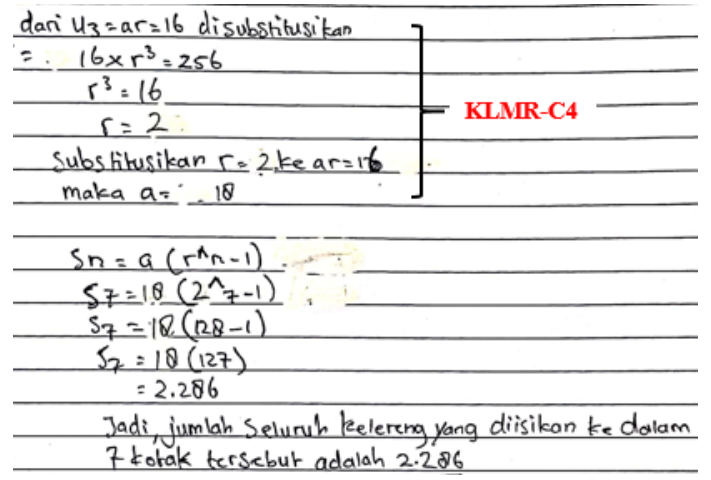

GAMBAR 9 Hasil Tes Siswa KLMR

Pada Gambar 9 siswa KLMR menggunakan metode subtitusi yang tidak jelas untuk menyelesaikan masalah (KLMR-C4). Siswa KLMR melakukan prosedur penyelesaian dengan tidak jelas untuk menemukan solusi yang tepat dari masalah yang diberikan (KLMR-C4). Selain itu, siswa KLMR melakukan kesalahan dalam perhitungan (KLMR-C4). Dalam hal ini, siswa KLMR kurang dapat melaksanakan penyelesaian masalah. 
Memeriksa kembali jawaban penyelesaian

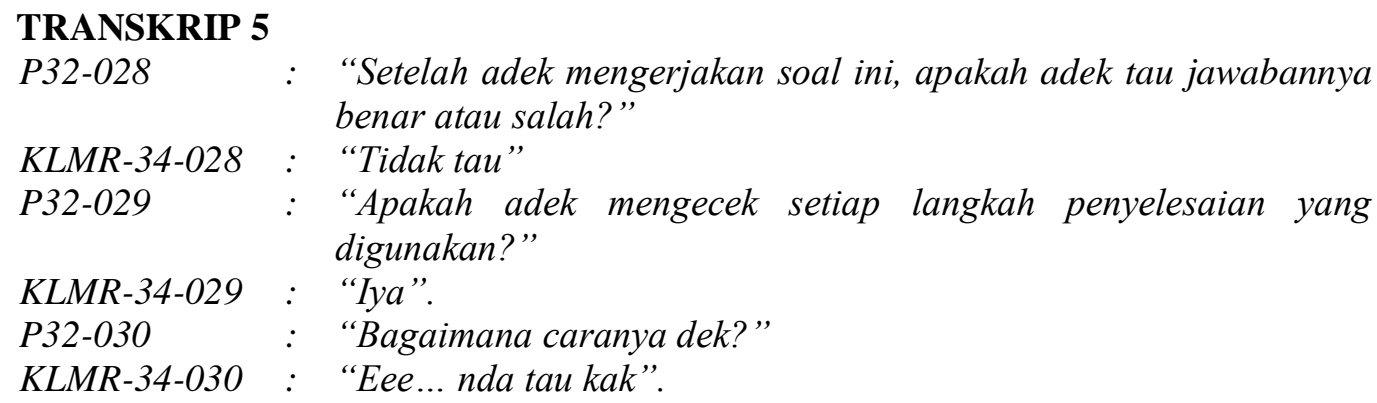

Pada Transkrip 5, siswa KLMR menjelaskan bahwa memeriksa kembali penyelesaian setelah mengerjakan soal yaitu mengecek kembali jawaban yang diperoleh (KLMR-34-029). Akan tetapi, siswa KLMR tidak mengetahui cara mengecek penyelesaian masalah yang dilakukan (KLMR-34-030). Selain itu, siswa KLMR tidak mengetahui jawaban yang diperoleh benar atau salah (KLMR-34-028).

Kemampuan pemecahan masalah matematika masing-masing tingkat kecerdasan logis matematis berbeda-beda. Siswa dengan kecerdasan logis matematis tinggi dapat melaksanakan langkah-langkah pemecahan masalah dengan baik. Sedangkan siswa dengan kecerdasan logis matematis sedang dan rendah melaksanakan langkah-langkah pemecahan masalah dengan beberapa kekeliruan.

\section{KESIMPULAN}

Kemampuan pemecahan masalah matematika siswa berbeda berdasarkan tingkat kecerdasan logis matematis siswa. Siswa KLMT mampu memahami masalah dengan mengungkapkan maksud soal secara lengkap dan tepat daripada siswa KLMS dan KLMR. Siswa KLMT dan KLMS mampu merencanakan penyelesaian masalah dengan tepat, sedangkan siswa KLMR kurang mampu menyusun rencana penyelesaian. Siswa KLMT dapat melaksanakan penyelesaian masalah dengan prosedur yang tepat, sedangkan siswa KLMS dan KLMR melakukan prosedur dengan kurang tepat. Siswa KLMT mampu memeriksa kembali proses penyelesaian masalah, sedangkan siswa KLMS cukup mampu memeriksa kembali proses penyelesaian dan siswa KLMR kurang mampu memeriksa kembali proses penyelesaian masalah. Dengan demikian perbedaan kemampuan pemecahan masalah matematika setiap tingkat kecerdasan logis matematis terlihat pada tahap memahami masalah dan melaksanakan rencana penyelesaian masalah.

Penelitian ini hanya mendeskripsikan kemampuan pemecahan masalah matematika siswa berdasarkan kecerdasan logis matematis. Jadi, diharapkan bagi peneliti lain untuk menganalisis kemampuan pemecahan masalah siswa agar dapat mengetahui lebih mendalam kemampuan pemecahan masalah siswa. Selain itu, menganalisis kemampuan pemecahan masalah matematika siswa berdasarkan jenis kecerdasan lain.

\section{DAFTAR PUSTAKA}

Amri, H, A. (2017). Profil Kemampuan Pemecahan Masalah Matematika Ditinjau dari Kecerdasan Majemuk (Kecerdasan Visual-Spasial Matematis Dan Kecerdasan LogisMatematis) Siswa Kelas $X$ Khusus SMA Negeri 3 Sengkang. (Tesis, tidak dipublikasikan). Program Pascasarjana Universitas Negeri Makassar, Makassar.

Armstrong, T. (2002). Menerapkan Multiple Intellegences di Sekolah. Bandung: Kaiffa.

Hudojo, H. (1990). Strategi mengajar Belajar Matematika. Malang: IKIP Malang. 
Irawan, EPI., Suharta, IGP., \& Suparta, NI. (2016). Faktor-Faktor Yang Mempengaruhi Kemampuan Pemecahan Masalah Matematika: Pengetahuan Awal, Apresiasi Matematika, Dan Kecerdasan Logis Matematis. Prosiding Seminar Nasional MIPA, (Online), ISBN 978-602-6428-00-4, (https://ejournal.undiksha.ac.id/index.php/semnasmipa/article/view/10185, diakses pada tanggal 10 Agustus 2018).

Jayantika, TIAI., \& Sudiarta, PGI. (2013). Kontribusi Bakat Numerik, Kecerdasan Spasial, dan Kecerdasan Logis Matematis Terhadap Prestasi Belajar Matematika Siswa SD Negeri Di Kabupaten Buleleng. e-Journal Program Pascasarjana Universitas Pendidikan Ganesha,2 (https://media.neliti.com/media/publications/102985-ID-kontribusi-bakatnumerik-kecerdasan-spas.pdf, diakses pada tanggal 30 Agustus 2018).

Mahalistia, E., \& Wijayanti, P. (2017). Penalaran Matematis Siswa Dalam Memecahkan Masalah Matematika Berdasarkan Kecerdasan Linguistik dan Logis-Matematis. Jurnal Pendidikan Ilmiah Matematika, 2(6) (http://jurnalmahasiswa.unesa.ac.id/index.php/mathedunesa/article/view/21124/19371, diakses pada tanggal 03 Oktober 2018).

Mahardhikawati, E., Mardiyana., \& Setiawan, R. (2017). Analisis Kemampuan Pemecahan Masalah Berdasarkan Langkah-Langkah Polya Pada Materi Turunan Fungsi Ditinjau dari Kecerdasan Logis-Matematis Siswa Kelas XI IPA SMA Negeri 7 Surakarta Tahun Ajaran 2013/2014. Jurnal Pendidikan Matematika dan Matematika (JPMM) Solusi, 1(4) (http://jurnal.fkip.uns.ac.id/index.php/matematika/issue/view/822, diakses pada tanggal 03 Oktober 2018).

Prasetyo, R, J. \& Andriani, Y. (2009). Multiply Your Multiple Intellegences "Melatih 8 Kecerdasan Majemuk pada Anak dan Dewasa”. Yogyakarta: Andi Offset.

Polya, G. (1973). How To Solve It. New Jersey: Princeton University Press.

Zulfairanatama, G., \& Hadi, S. 2013. Kecerdasan Logika Matematika Berdasarkan Multiple Intelligences Terhadap Kemampuan Matematika Siswa SMP di Banjarmasin. EDUMAT Jurnal Pendidikan Matematika, 1(1) (http://download.portalgaruda.org/, diakses pada tanggal 10 Desember 2018). 